\title{
Effects of Cannabinoids on Caffeine Contractures in Slow and Fast Skeletal Muscle Fibers of the Frog
}

\author{
Miguel Huerta $\cdot$ Mónica Ortiz-Mesina $\cdot$ Xóchitl Trujillo $\cdot$ \\ Enrique Sánchez-Pastor · Clemente Vásquez · Elena Castro • \\ Raymundo Velasco · Rocío Montoya-Pérez · Carlos Onetti
}

Received: 23 November 2008/Accepted: 8 May 2009/Published online: 9 June 2009

(c) The Author(s) 2009. This article is published with open access at Springerlink.com

\begin{abstract}
The effect of cannabinoids on caffeine contractures was investigated in slow and fast skeletal muscle fibers using isometric tension recording. In slow muscle fibers, WIN 55,212-2 (10 and $5 \mu \mathrm{M})$ caused a decrease in tension. These doses reduced maximum tension to $67.43 \pm 8.07 \%(P=0.02, n=5)$ and $79.4 \pm 14.11 \%$ $(P=0.007, n=5)$ compared to control, respectively. Tension-time integral was reduced to $58.37 \pm 7.17 \%$ and $75.10 \pm 3.60 \%(P=0.002, n=5)$, respectively. Using the $\mathrm{CB}_{1}$ cannabinoid receptor agonist ACPA $(1 \mu \mathrm{M})$ reduced the maximum tension of caffeine contractures by $68.70 \pm 11.63 \%(P=0.01, n=5)$; tension-time integral was reduced by $66.82 \pm 6.89 \%(P=0.02, n=5)$ compared to controls. When the $\mathrm{CB}_{1}$ receptor antagonist AM281 was coapplied with ACPA, it reversed the effect of ACPA on caffeine-evoked tension. In slow and fast muscle fibers incubated with the pertussis toxin, ACPA had no effect on tension evoked by caffeine. In fast muscle fibers, ACPA $(1 \mu \mathrm{M})$ also decreased tension; the maximum tension was reduced by $56.48 \pm 3.4 \%(P=0.001, n=4)$, and tension-time integral was reduced by $57.81 \pm 2.6 \%$ $(P=0.006, n=4)$. This ACPA effect was not statistically significant with respect to the reduction in tension in slow
\end{abstract}

M. Huerta $\cdot$ M. Ortiz-Mesina $\cdot$ X. Trujillo ( $\bowtie) \cdot$

E. Sánchez-Pastor · C. Vásquez · E. Castro ·

R. Montoya-Pérez · C. Onetti

Unidad de Investigación Dr. Enrico Stefani del, Centro

Universitario de Investigaciones Biomédicas, Universidad de

Colima, Avenida 25 de julio \# 965, Colonia Villa San Sebastián,

Apartado Postal No. 11, C.P. 28040 Colima, Colima, México

e-mail: rosio@cgic.ucol.mx

\section{R. Velasco}

Facultad de Enfermería, Universidad de Colima, Avenida Universidad \# 333, Col. Las Víboras, C.P. 28040 Colima, Colima, México muscle fibers. Moreover, we detected the presence of mRNA for the cannabinoid $\mathrm{CB}_{1}$ receptor on fast and slow skeletal muscle fibers, which was significantly higher in fast compared to slow muscle fiber expression. In conclusion, our results suggest that in the slow and fast muscle fibers of the frog cannabinoids diminish caffeine-evoked tension through a receptor-mediated mechanism.

Keywords Cannabinoid receptor - Agonist WIN 55,212-2 - Agonist ACPA - Antagonist AM281 . Caffeine contracture $\cdot$ Skeletal muscle

\section{Introduction}

Cannabinoids exert diverse biological effects on tissues by acting at cannabinoid receptors, which belong to the superfamily of $\mathrm{G}_{\mathrm{i}} / \mathrm{G}_{\mathrm{o}}$ protein-coupled receptors (Matsuda et al. 1990), which are sensitive to pertussis toxin (Reisine and Law 1992; Soderstrom et al. 2000). To date, two cannabinoid receptors have been identified $\left(\mathrm{CB}_{1}\right.$ and $\left.\mathrm{CB}_{2}\right)$; the $\mathrm{CB}_{1}$ receptor is mainly located within the central nervous system but also in peripheral tissues; the $\mathrm{CB}_{2}$ receptor is found predominantly in the immune system (Chaperon and Thiebot 1999; Matsuda et al. 1990) and is also expressed by some neurons (Beltramo et al. 2006; Gong et al. 2006). In the brain, $\mathrm{CB}_{1}$ receptors are highly localized in the hippocampus, cerebellum and substantia nigra (Glass et al. 1997). They are also located presynaptically on peripheral nerves in gut, vas deferens, bladder (Pertwee et al. 1996), immune (Munro et al. 1993; Parolaro 1999) and smooth muscle cells (Filipeanu et al. 1997). However, cannabinoid receptors also occur postsynaptically, e.g., in the hippocampus and in skeletal muscle (Cavuoto et al. 2007a; Ortiz-Mesina et al. 2007). Cannabinoids also bind 
to vanilloid receptors subtype 1 (VR) (Ross 2003), which are expressed in skeletal muscle (Xin et al. 2005; Cavuoto et al. 2007b).

The endogenous cannabinoid system, represented by cannabinoid receptors, appeared early in evolution and has been conserved (Salzet et al. 2000; McPatland et al. 2006). In amphibians, to date only the $\mathrm{CB}_{1}$ ortholog receptor has been found (McPatland et al. 2006; Salzet et al. 2000). Soderstrom et al. (2000) reported the expression of $\mathrm{CB}_{1}$ in different tissues of newt including skeletal muscle. Salio et al. (2002) studied the distribution of $\mathrm{CB}_{1}$ receptors in amphibian spinal cord. In 2006, Meccariello et al. reported the expression of $\mathrm{CB}_{1}$ in several tissues of Rana esculenta. Hollis et al. (2006) also reported the existence of $\mathrm{CB}_{1}$ receptor in the newt brain. In $R$. pipiens, Sánchez-Pastor et al. (2007) showed pharmacological evidence indicating the functional presence of $\mathrm{CB}_{1}$ receptors in the neuromuscular junction.

Cannabinoids reduce locomotor activity. These effects could be due to actions on the central nervous system (Dewey 1986; Sañudo-Pena et al. 2000). Some effects of cannabinoids have suggested their potential therapeutic use (as muscle relaxants or reducers of motor activity) (Baker et al. 2000, 2001; Mackie 2006). However, more basic research is required before their real value can be assessed. To this end, we designed the present study to evaluate the direct action of cannabinoids on contraction of skeletal muscles, hoping to find a physiological basis for some of their effects on spasticity, spontaneous muscle activity and reduction of motor activity (Baker et al. 2000, 2001; DiMarzo et al. 2000; Mackie 2006; Sañudo-Pena et al. 2000). Our primary aim was to examine the effects of the $\mathrm{CB}_{1}$ cannabinoid agonists WIN 55,212-2 and arachidonylcyclopropylamide (ACPA) on caffeine contractures in slow and fast skeletal muscle fibers of $R$. pipiens. In addition, in this study we found mRNA for the $\mathrm{CB}_{1}$ receptor in frog skeletal muscle. The presence of mRNA was determined semiquantitatively and quantitatively by PCR. Some of these results have been previously published as abstracts (Ortiz-Mesina et al. 2007; Sánchez-Pastor et al. 2004).

\section{Methods}

\section{Muscle Preparation}

The study was performed on extensor digitorum longus digiti IV and cruralis muscles or bundles $(0.5 \mathrm{~mm}$ diameter) from $R$. pipiens by doing molecular biology experiments or by means of isometric tension recordings. Frogs were used in accordance with the Institute for Laboratory Animal Research's Guide for the Care and Use of
Laboratory Animals (1996) and Alworth and Harvey (2007). They were kept at room temperature $\left(22-24^{\circ} \mathrm{C}\right)$ and fed with a mixture of chicken liver and cod liver oil. To minimize pain and distress, under cold anesthesia frogs were killed and demedullated to extract the muscles.

\section{Tension Recording}

A continuous-perfusion recording chamber with an adjustable width and a central channel $3 \mathrm{~cm}$ long was used to record tension in the bundles. The proximal end of each bundle was fixed to the wall of the chamber, while the distal end was hooked up to the lever of a linear mechanoelectrical transducer (400A; Cambridge Technology, Cambridge, MA). The bundle was stretched to 1.3 times its resting length before any isometric-tension recording was performed. Caffeine contractures were $240 \mathrm{~s}$ of duration for slow muscle fibers and $80 \mathrm{~s}$ for the fast muscle fibers. Solutions entered via a three-way tap situated at one end of the central channel. Mechanical responses were evoked by caffeine solution (see "Solutions"), both in the control trials and after addition of an agonist or antagonist for the cannabinoid receptors (WIN 55,212-2, ACPA or AM281; Tocris Bioscience, Ellisville, MO). A data-acquisition system (CyberAmp 320; Axon Instruments, Foster City, CA) and a Digidata 1200 (Axon Instruments) were used to process and to store the data in a computer (Pentium 4) for subsequent analysis. AxoScope software (pClamp 9.0, Axon Instruments) was used for data acquisition and the program Clampfit, for data analysis.

\section{Extracting the tRNA to Detect $\mathrm{CB}_{1}$ in Extensor Digitorum Longus and Cruralis Muscles}

To extract tRNA, the procedures described by Chomczynski and Sacchi (1987) were used. In brief, $10 \mathrm{mg}$ of extensor digitorum longus IV or cruralis muscle in PBS solution (Invitrogen 10010-023; GIBCO, Rockville, MD) were extracted and transferred to a $1.5-\mathrm{ml}$ tube containing $0.5 \mathrm{ml}$ Trizol (15596-018; Invitrogen, Carlsbad, CA). The tissue was homogenized, and total RNA was then extracted using phenol-chloroform and isopropanol. To determine the quality of RNA, electrophoresis was carried out on 1-2 $\mu \mathrm{g}$ of the total RNA using $1 \%$ agarose gel. To identify the expression of $\mathrm{CB}_{1}$ in skeletal muscle fibers of the frog, we made a comparison of the published sequences in GeneBank Delta mRNA for several species, and primers were designed considering the conserved sequences having as base template the Xenopus laevis sequence. Thus, the sequence used was 5'-GCAGTGTAATTTTTGTCTACAG-3' (sense) and 5'-GAGGGCCCCAACAAATGATT$3^{\prime}$ (antisense). As a positive control for $\mathrm{CB}_{1}$ receptor expression, $\mathrm{CaCl}_{2}$ precipitation was used to transfect $70 \%$ 
confluent HEK293 cells with a plasmid containing the coding sequence for human $\mathrm{CB}_{1}$ cannabinoid receptor. The cDNA for $\mathrm{CB}_{1}$, inserted into the mammalian expression vector pCI (Promega, Madisson, WI), was expressed under the control of a cytomegalovirus (CMV) promoter. HEK293 cell culture was grown at $37^{\circ} \mathrm{C}$ in Dulbecco's modified eagle medium (GIBCO) containing 10\% horse serum and $1 \%$ antibiotic-antimycotic, under a $5 \% \mathrm{CO}_{2}$ atmosphere. To carry out reverse-transcriptase polymerase chain reaction (RT-PCR), a SuperScript ${ }^{\mathrm{TM}}$ one-step RTPCR with a Platinum ${ }^{\circledR}$ Taq kit (Invitrogen) was used and 4 $\mu \mathrm{g}$ of the total RNA from the extensor digitorum longus or cruralis muscles was added. A DNA thermal cycler (iCycler; Bio-Rad Laboratories, Hercules, CA) was used, and the protocol consisted of the following cycles: (1) to synthesize and denaturalize cDNA, we started with a $50^{\circ} \mathrm{C}$ cycle for $30 \mathrm{~min}$, followed by a 2 -min cycle at $90^{\circ} \mathrm{C}$; (2) then, we amplified the cDNA using 40 cycles (each of $15 \mathrm{~s}$ at $94^{\circ} \mathrm{C}, 30 \mathrm{~s}$ at $50^{\circ} \mathrm{C}$ and $1 \mathrm{~min}$ at $72^{\circ} \mathrm{C}$ ); and (3) we finished with a final 8 -min cycle at $72^{\circ} \mathrm{C}$. The total reaction mix used for this RT-PCR $(50 \mu \mathrm{l})$ contained $4 \mu \mathrm{g}$ of total muscle RNA, $1 \mathrm{~nm}$ of each of the primers, $25 \mu \mathrm{l}$ $2 \times$ reaction mix, $1 \mu \mathrm{l}$ RT/Platinum Taq Mix and $1 \mu \mathrm{l}$ of $5 \mathrm{~mm} \mathrm{MgSO}_{4}$. The anticipated size for $\mathrm{CB}_{1}$ receptor mRNA was 579 bp compared with 1,053 bp for $\beta$-actin mRNA. Electrophoresis of the RT-PCR products to separate the components was done on a $1 \%$ agarose gel. Signals were analyzed using Quantity one, version 9.2.1 (Bio-Rad Laboratories).

\section{Real-Time RT-PCR}

Real-time RT-PCR was performed according to SuperScript $^{\mathrm{TM}}$ one-step methods using a real-time RT-PCR thermal cycler (Rotor-Gene 3000; Corbett Life Science, Sydney, Australia). Thus, the cocktail was prepared exactly as for conventional RT-PCR but adding the fluorophore SYBR green (SuperArray, Frederick, MD). The fluorescence of the SYBR green indicated the expression level for $\mathrm{CB}_{1}$ mRNA, and this was compared with an mRNA sample of known concentration used as control. Analysis was done using Rotor-Gene 5 software (Corbett Life Science).

\section{Solutions}

The normal saline solution contained (in $\mathrm{mm}$ ) $\mathrm{NaCl} 117.5$, $\mathrm{KCl} 2.5$ and $\mathrm{CaCl}_{2}$ 1.8. The $\mathrm{pH}$ was adjusted to 7.4 with imidazole $\mathrm{Cl}$. Contractures were induced following rapid substitution (1-2s) of the normal solution by caffeine solution (normal saline solution plus caffeine $6 \mathrm{~mm}$ ). In mechanical experiments, the bundle was curarized with 50 $\mu \mathrm{M} d$-tubocurarine (Sigma, St. Louis, MO). Stock solutions of WIN 55,212-2, ACPA and AM281-1-(2,4- dichlorophenyl)-5-(4-iodophenyl)-4-methyl- $N$-4-morpholinyl- $1 H$-pyrazole-3-carboxamide (Tocris Cookson, Ballwin, MO) - at $10 \mathrm{~mm}$ concentration were made up in dimethyl sulfoxide (DMSO) or ethanol (Sigma). The final concentration of DMSO in the bathing solution was $<0.01 \%$, which has no significant effect on caffeine or $\mathrm{K}^{+}$contractures (Velasco et al. 2003). The cruralis bundles were incubated in the appropriate solution for $5 \mathrm{~min}$ before contractures were induced using caffeine. When ACPA was used, the experiments were performed in the dark. Pertussis toxin (PTX; Sigma-Aldrich, St. Louis, MO) was applied by incubating the muscle with $2 \mu \mathrm{g} / \mathrm{ml}$ PTX in normal saline solution at $4^{\circ} \mathrm{C}$ for $22-24 \mathrm{~h}$ before doing experiments (Sugiura and Ko 1997). Experiments were performed at room temperature $\left(22-24^{\circ} \mathrm{C}\right)$. PTX was reconstituted as a stock solution $(50 \mu \mathrm{g} / \mathrm{ml})$ with $5 \mathrm{mg} / \mathrm{ml}$ of bovine serum albumin (BSA, Sigma) solution in water. Control experiments were done by incubating muscles in a solution of BSA.

\section{Data Analysis}

Tension analysis was performed using the Clampfit subroutine (pClamp 9.0 software, Axon Instruments). Graphics were generated by Sigmaplot 8.0 software (Systat Software, San Jose, CA). The analyzed parameters of the contracture were maximum tension (peak tension) and tension-time integral (total tension). The experimental results are presented as means \pm standard error. Mean data were subjected to Student's $t$-test; differences were considered significant at $P<0.05$.

\section{Results}

Presence of mRNA for Cannabinoid Receptor $\mathrm{CB}_{1}$ in Skeletal Muscle Fibers

$\mathrm{CB}_{1}$ receptors are broadly localized in the central nervous system and in some peripheral tissues, but the presence of these kinds of receptors in skeletal muscle has not been determined. The presence of $\mathrm{CB}_{1}$ receptor mRNA was determined in frog fast and slow skeletal muscle fibers. Fast muscle fibers were obtained from the extensor digitorum longus muscle and slow muscle fibers, from tonic bundles of cruralis muscle. In Fig. 1, lane 2 shows untransfected HEK293 cells (negative control). Lane 3 shows HEK293 cells transfected with $\mathrm{CB}_{1}$ (positive control). The expected size for $\mathrm{CB}_{1}$ was $579 \mathrm{bp}$. Lanes 4 and 5 show the expression of $\mathrm{CB}_{1}$ receptors in fast and slow skeletal muscle fibers, respectively. As can be seen, $\mathrm{CB}_{1}$ expression is very abundant in fast skeletal muscle fibers (lane 4) as its expression is comparable with induced 


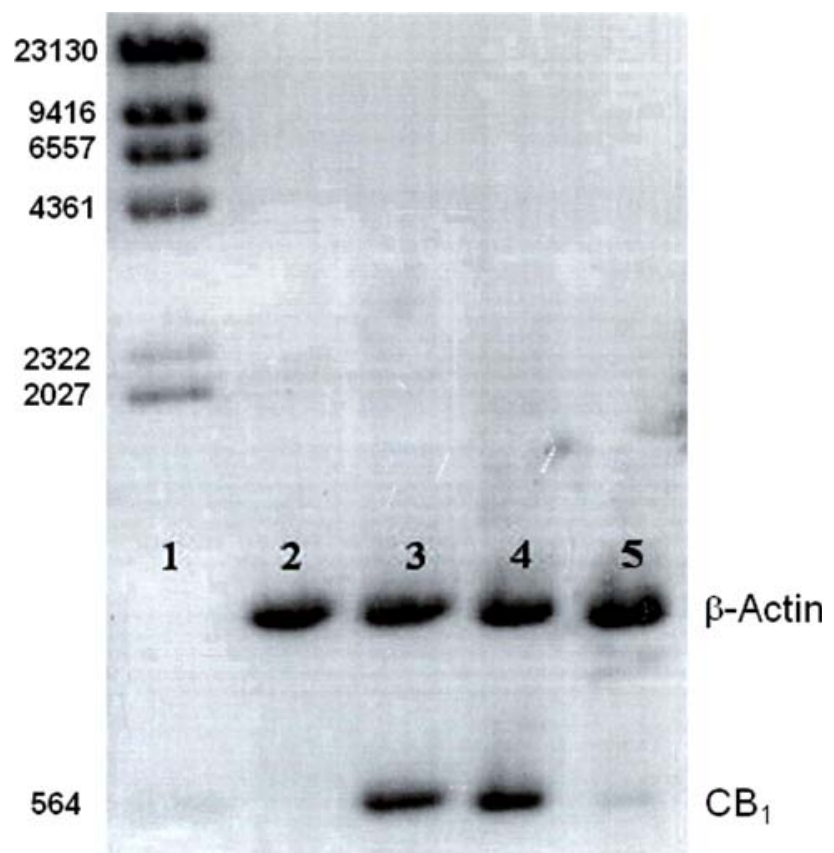

Fig. 1 A 1\% agarose gel showing electrophoresis results for RT-PCR analysis of $\mathrm{CB}_{1}$ receptor. Lane 1, HindIII; lane 2, nontransfected HEK293 cells; lane 3, transfected HEK293 cells; lane 4, frog fast extensor digitorum longus muscle; lane 5 , frog slow cruralis muscle; lane 6, HindIII. All lanes contained actin and the $\mathrm{CB}_{1}$ primers

expression in HEK cells (lane 3). On the other hand, although to a lesser extent, slow muscle fibers also express mRNA for $\mathrm{CB}_{1}$, shown as a faint but visible band in lane 5 . Expression of $\beta$-actin was used as a control for RNA quality. The relationship to the mRNA expression for $\mathrm{CB}_{1} /$ $\beta$-actin was $0.99 \pm 0.03$ for fast muscle fibers and $0.51 \pm 0.10$ for slow muscle fibers. The difference was statistically significant $(P=0.002, n=6)$. Thus, $\mathrm{CB}_{1}$ receptors are present in both fast and slow skeletal muscle fibers of the frog.

\section{Real-Time RT-PCR}

To further confirm the existence of mRNA for $\mathrm{CB}_{1}$ in frog skeletal muscle fibers, we did quantitative analysis of $\mathrm{CB}_{1}$ mRNA levels using real-time RT-PCR. The mRNA expression levels of $\mathrm{CB}_{1}$ receptors were checked by the intensity of fluorescence produced by SYBR green. As with conventional RT-PCR, the expression levels were lower in slow muscle fibers than in fast muscle fibers (Fig. 2). The concentration levels for $\mathrm{CB}_{1}$ mRNA corroborate the approximate $2: 1$ relationship between fast and slow muscle fibers, which was $5.07 \mu \mathrm{g} / \mu \mathrm{l}$ for the fast muscle fibers and $2.60 \mu \mathrm{g} / \mu \mathrm{l}$ for the slow muscle fibers. To determine the $\mathrm{CB}_{1}$ mRNA concentrations, we used a sample with known mRNA concentration as a control.

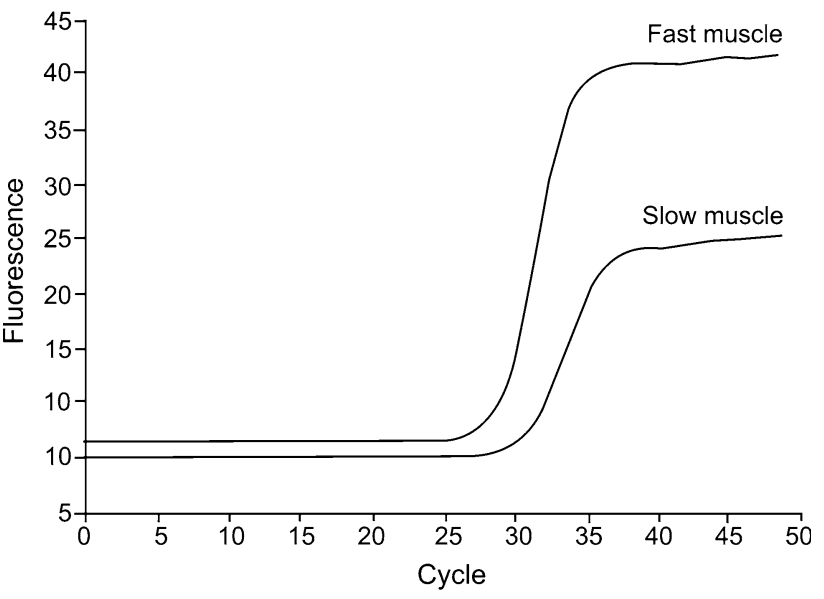

Fig. 2 RT-PCR expression levels for $\mathrm{CB}_{1}$ mRNA in fast and slow frog muscles. As can be seen, fluorescence began earlier in the fast muscle (around cycle 25 vs. cycle 27 for the slow muscle). The values for $\mathrm{CB}_{1}$ mRNA concentrations were $5.07 \mu \mathrm{g} / \mu \mathrm{l}$ for fast muscle fibers and $2.60 \mu \mathrm{g} / \mu \mathrm{l}$ for slow muscle fibers. To determine the concentrations of $\mathrm{CB}_{1}$ mRNA, a known mRNA concentration was used as a control

\section{Effects of WIN 55,212-2 on Caffeine Contractures} in Slow Muscle Fibers

It is known that cannabinoids can affect muscle activity (Baker et al. 2000, 2001; DiMarzo et al. 2000; Mackie 2006; Sañudo-Pena et al. 2000), but little information exists about the mechanism of action of cannabinoids on skeletal muscle. To determine whether cannabinoids directly modulate tension in slow skeletal muscle fibers, we used the cannabinoid agonist WIN 55,212-2. WIN was added to the external medium $5 \mathrm{~min}$ previous, to induce the caffeine contracture, and kept throughout the contracture. Addition of this agonist $(10 \mu \mathrm{M})$ to the external medium decreased the tension evoked by $6 \mathrm{~mm}$ of caffeine; the maximum tension was clearly reduced to $67.43 \pm 8.07 \%$ $(P=0.02, n=5)$, while tension-time integral was reduced to $58.37 \pm 7.17 \%(P=0.0001, n=5)$, compared to the control (Fig. 3a). Figure $3 \mathrm{~b}$ shows caffeine contractures in normal solution before and after adding WIN 5 $\mu \mathrm{M}$; the maximum tension was reduced to $79.4 \pm 14.11 \%$ $(P=0.007, n=5)$, while tension-time integral was reduced to $75.1 \pm 3.6 \%(P=0.002, n=5)$. Thus, WIN at different concentrations reduces the tension of caffeine contractures in slow skeletal muscle fibers.

\section{Effects of ACPA on Caffeine Contractures in Slow Muscle Fibers}

To further corroborate that cannabinoids can modulate tension in skeletal muscle fibers, we examined the effects of a selective agonist of $\mathrm{CB}_{1}$ receptors, ACPA, which is analogous to the endocannabinoid anandamide (Hillard 


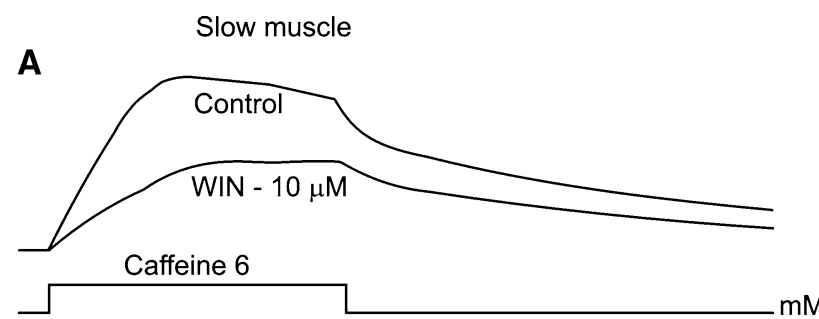

B

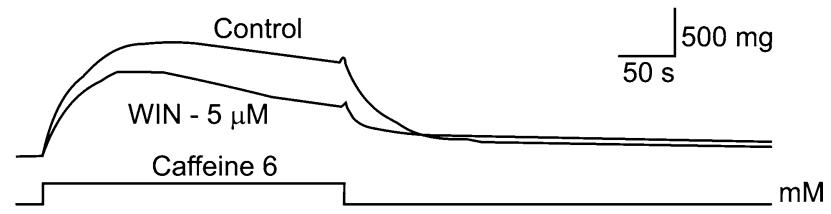

Fig. 3 Effects of WIN 55,212-2 on caffeine contractures in slow muscle fibers. In $\mathbf{a}$ and $\mathbf{b}$, tension decreased in the presence of WIN 55,212-2 (10 and $5 \mu \mathrm{M}$, respectively). Control caffeine contractures in normal solution are also shown (upper records). This effect of WIN 55,212-2 was reversible. Different muscle bundles were used for each experiment

et al. 1999). For these experiments, we used slow skeletal muscle fibers. In these experiments, $1 \mu \mathrm{M}$ of ACPA was applied during contractures induced with caffeine $(6 \mathrm{~mm})$. Figure 4 shows the results that we obtained. Figure 4a shows caffeine contractures in a normal solution (control) and when ACPA was applied to the bathing solution, which decreased the muscle tension. Maximum tension was clearly reduced compared to the control-by $68.70 \pm 11.63 \%(P=0.01, n=5)$ - while tension-time integral was reduced by $66.12 \pm 6.89 \% \quad(P=0.02$, $n=5$ ). In addition, other caffeine concentrations (4 and $8 \mathrm{~mm}$ ) were used to evoke contractures (data not shown). Compared to the control and using $8 \mathrm{~mm}$ of caffeine, $1 \mu \mathrm{M}$ of ACPA reduced the maximum tension by $77.56 \pm 6.43 \%$ $(P=0.08)$, while tension-time integral was reduced by $75.46 \pm 5.55 \%(P=0.002, n=5)$. With $4 \mathrm{~mm}$ caffeine, the same concentration of ACPA reduced the maximum tension by $80.40 \pm 8.25 \%(P=0.003)$ and tension-time integral by $80.81 \pm 10.14 \%(P=0.002)$ compared to the control $(n=5)$. Thus, these results with ACPA corroborate that, in frog slow skeletal muscle fibers, the cannabinoids reduce tension evoked by caffeine.

\section{Effects of Antagonist AM281 on Caffeine Contractures in Slow Muscle Fibers}

Next, we tested whether the high-affinity $\mathrm{CB}_{1}$ receptor antagonist AM281 (Howlett et al. 2002) can block the effects of ACPA. We incubated the muscle in the recording solution containing AM281 $(1 \mu \mathrm{M}) 5$ min before we added ACPA $(1 \mu \mathrm{M})$ to the bath and kept it in the solution until the contracture was finished. AM281 reversed the inhibitory effect observed with ACPA alone on caffeineevoked tension in these slow muscle fibers. As Fig. 4b shows, maximum tension was reduced to $90.27 \pm 3.07 \%$ compared to the control and tension-time integral was not significantly modified $(100.24 \pm 10.91 \%, n=5)$, suggesting that ACPA modulates caffeine contractions by interacting with $\mathrm{CB}_{1}$ receptors. Nevertheless, we still observed a small decrease in the contractures, which could have been due to a nonrelated activation of the $\mathrm{CB}_{1}$ receptors by ACPA as the reduction in tension produced by ACPA was not fully reversed by AM281. Control experiments recording caffeine contractures in the presence of AM281 alone were also performed, and these showed no significant effect (data not shown). These results indicate that ACPA reduces the caffeine-induced contracture of slow skeletal muscle fibers mainly by the activation of $\mathrm{CB}_{1}$ receptors.

\section{Effect of PTX on Caffeine Contractures in Slow Muscle} Fibers

Cannabinoid receptors belong to the $\mathrm{G}$ protein-coupled receptor family. To test whether the observed ACPA effects are mediated through $\mathrm{G}_{\mathrm{i} / \mathrm{o}}$ proteins, we incubated the cruralis muscles with PTX $(2 \mu \mathrm{g} / \mathrm{ml})$. Figure $4 \mathrm{c}$ shows the results of the experiments under these conditions. In slow muscle fibers incubated with PTX, $1 \mu \mathrm{M}$ of ACPA
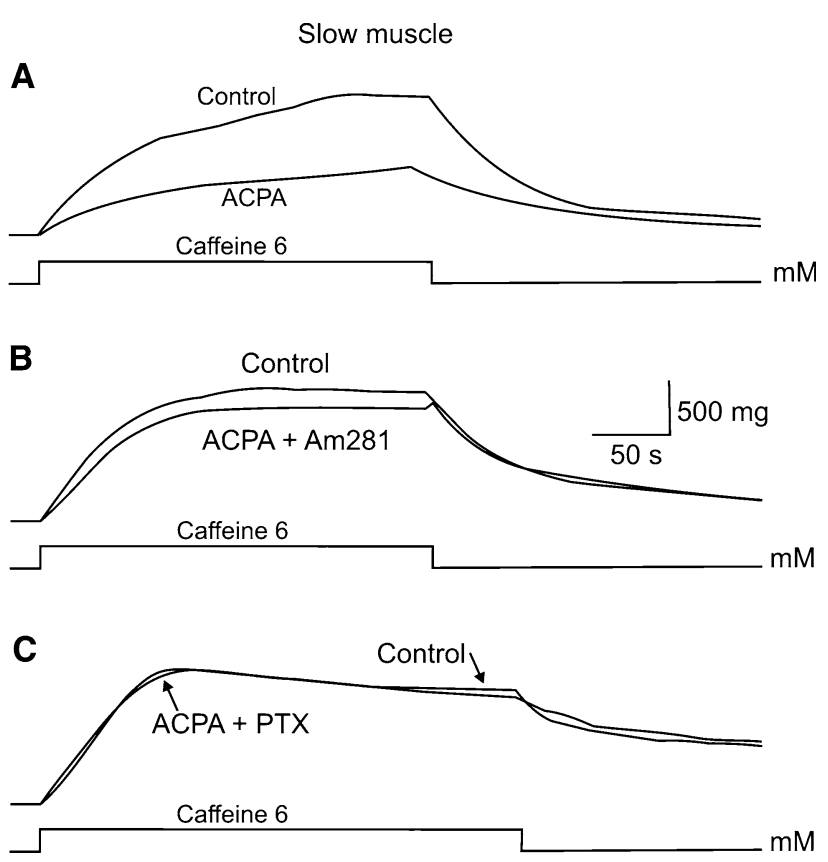

Fig. 4 Effects of ACPA $(1 \mu \mathrm{M})$ on tension evoked by caffeine in slow skeletal muscle fibers. a-c Caffeine contractures in normal solution (upper records). a The decrease in tension with ACPA. b Antagonist AM281 $(1 \mu \mathrm{M})$ was coapplied with ACPA, which reversed the inhibitory effect of ACPA. c ACPA was applied to a bundle previously incubated with PTX 
had no effect on tension evoked by caffeine. The maximum tension in the presence of ACPA, on average, was $95.69 \pm 9.39 \%$, and tension-time integral was $97.69 \pm 13.37 \%(n=5)$. These data suggest that ACPA acts mostly through a mechanism that involves $G_{i / o}$ proteins. Control experiments were done in parallel, and no significant effect with PTX incubation was observed (data not shown).

Effect of ACPA on Caffeine Contractures in Fast Muscle Fibers

To investigate whether cannabinoids also can modulate tension in fast muscle fibers, we studied the effects of the selective $\mathrm{CB}_{1}$ receptor agonist ACPA. When fast muscle fibers were incubated with ACPA $(1 \mu \mathrm{M})$, it reduced the maximum tension of the caffeine contracture by $56.48 \pm 3.4 \%(P=0.001, n=4)$, and tension-time integral was reduced by $57.81 \pm 2.60 \%(P=0.006, n=4)$ in the second caffeine contracture (Fig. 5). This ACPA effect was not statistically different with respect to reduction in tension in the slow muscle fibers $(P>0.05)$. When the $\mathrm{CB}_{1}$ antagonist receptor AM281 $(1 \mu \mathrm{M})$ was coapplied with ACPA, it largely reversed the effect of ACPA on caffeine-evoked tension. Maximum tension was reduced to $87.37 \pm 1.7 \%(P=0.01, n=3)$ and tension-time integral to $89.77 \pm 1.73 \%(P=0.02, n=3)$.

Furthermore, to test whether the effects of ACPA are mediated through $\mathrm{G}_{\mathrm{i} / \mathrm{o}}$ proteins, we conducted experiments preincubating the muscles with PTX. After incubating the fast muscle fibers with PTX $(2 \mu \mathrm{g} / \mathrm{ml})$, ACPA had no effect on caffeine contractures $(n=3)$. These results are similar to those reported above for slow fibers (Fig. 4c). When we used the cannabinoid agonist WIN 55,212-2 at a concentration of $5 \mu \mathrm{M}$, this agonist produced a reduction in the maximum tension of caffeine contracture to $81.16 \pm 0.97 \% \quad(P=0.003, n=4)$ and tension-time integral was reduced to $72.15 \pm 4.35 \% \quad(P=0.007$, $n=4$ ), with respect to control. These results suggest that both ACPA and WIN reduced tension in the fast muscle fibers as well.

Fast muscle

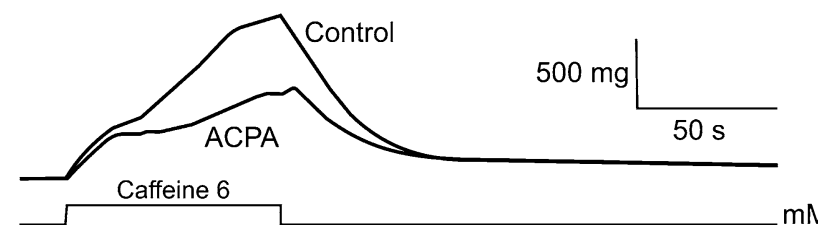

Fig. 5 Effects of ACPA on caffeine contracture in fast muscle fibers. Experiments were done using extensor digitorum longus IV muscle. Tension evoked by caffeine shows a great reduction in the presence of ACPA $(1 \mu \mathrm{M})$ compared to control tension

\section{Discussion}

Frog skeletal muscle possesses two main different types of fibers: twitch or fast and slow or tonic. Fast fibers give a transient contracture in high potassium; in contrast, slow fibers generate a prolonged contracture under similar conditions (Kuffler and Vaughan-Williams 1953; Huerta et al. 1986). This study has shown that the mRNA for the cannabinoid receptor $\mathrm{CB}_{1}$ is present in the frog's fast and slow skeletal muscle fibers. Although we cannot rule out that part of the $C_{1}$ receptor mRNA that we found was at the level of the nerve terminal, we used thin bundles that we carefully cleaned, removing vessels and nerves using glass dissectors to minimize the nerve terminals as possible sources of mRNA. The slow muscle fibers that we used were dissected from the tonic bundle of the cruralis muscle, while the fast muscle fibers were obtained from the extensor digitorum longus digit IV. It is known that fast muscle fibers are normally mono-innervated, in contrast to slow fibers, which are multi-innervated. We found that the mRNA expression levels for the $\mathrm{CB}_{1}$ receptor are lower in slow skeletal muscle fibers than in fast muscle fibers. These results are consistent with the evidence that only the ortholog $\mathrm{CB}_{1}$ receptor has been reported in amphibians (McPatland et al. 2006; Salzet et al. 2000; Wiley and Martin 2003; Soderstrom et al. 2000; Salio et al. 2002; Meccariello et al. 2006; Hollis et al. 2006; Sánchez-Pastor et al. 2007). Recently, the presence of $\mathrm{CB}_{1}$ receptors, found by RT-PCR, was reported in human skeletal muscle and the murine soleus muscle (both of which contain mainly slow muscle fibers) (Krippeit-Drews and Schmidt 1992; Pagotto et al. 2006; Cavuoto et al. 2007a). Those results are in agreement with our findings in this work with slow muscle fibers, and we also show the presence of $\mathrm{CB}_{1}$ receptors in fast skeletal muscle fibers. $\mathrm{CB}_{1}$ receptors are mostly localized presynaptically (Schlicker and Kathmann 2001), but they also occur postsynaptically, e.g., in the hippocampus (Schweitzer 2000). Also, we recently found indirect pharmacological evidence of the presence of $\mathrm{CB}_{1}$ receptors in frog fast skeletal muscle fibers (Sánchez-Pastor et al. 2007).

Cannabinoid receptors are part of the endocannabinoid system, which comprises cannabinoid receptors, along with the endogenous cannabinoids (endocannabinoids) and the enzymes that synthesize and degrade them. The bestknown endocannabinoid is anandamide, which is formed in the same cell as the $\mathrm{CB}_{1}$ receptor through which it acts. It can diffuse through the plasmalemma and can also be released from the extracellular fluid touching the presynaptic terminal (Piomelli 2003; Rodriguez de Fonseca et al. 2005). Therefore, in this study we mainly used ACPA, which is analogous to the endocannabinoid anandamide (Hillard et al. 1999; Sánchez-Pastor et al. 2007). 
We used caffeine to induce muscle tension since it is well known that caffeine evokes maintained tension in fast and slow fibers, mainly by calcium release from the sarcoplasmic reticulum (Caputo 1966; Klein et al. 1990; Muñiz et al. 1992). Moreover, in slow fibers Shabala et al. (2008) suggest that caffeine also opens the L-type $\mathrm{Ca}^{2+}$ channels from the sarcolemma. To investigate the possible direct effect of cannabinoids on skeletal muscle contraction, we induced caffeine contractures in the presence of WIN 55,212-2, causing a diminution in maximum tension and tension-time integral compared to the control. The effect of WIN 55,212-2 was reversible and dependent on the concentration.

To further investigate the effects of cannabinoids on skeletal muscle contraction, we also used the synthetic $\mathrm{CB}_{1}$-selective agonist ACPA. The results of these experiments show that the cannabinoid ACPA, at $1 \mu \mathrm{M}$, decreased both the maximum and the tension-time integral of the caffeine contracture in slow and fast muscle fibers. Moreover, this effect of ACPA on fast muscle fibers was observed until the second contracture, in contrast to WIN in slow muscle fibers, which showed an effect since the first contracture. More studies are necessary to clarify this mechanism. The antagonist of the $\mathrm{CB}_{1}$ receptors, AM281, reversed this effect. In addition, both types of muscle fibers were incubated with PTX, and ACPA had no effect on the tension evoked by caffeine. Our data suggest that ACPA acts through a mechanism involving $\mathrm{G}_{\mathrm{i} / \mathrm{o}}$ proteins, and the effect of ACPA is probably mediated by a decrease in intracellular cAMP. With respect to ACPA, WIN and the antagonist AM281 concentration used in this study, similar concentrations have been used in previous studies on these tissues (e.g., Sánchez-Pastor et al. 2007). On the other hand, in contrast with the high level of mRNA expression that we found in the fast compared to the slow muscle fibers, the effects of cannabinoids on the induced contractures in these two types of muscle fibers were similar. One reason could be that even though the mRNA expression level is higher in the fast type, the level of protein to transcribe is lower than in the slow type (Greenbaum et al. 2003). Another explanation is the fact that the intracellular machinery involved in the mechanisms used by cannabinoids to modulate tension is different in both types of muscle fibers as well as the excitation-contraction coupling, which is different (Huerta et al. 1986).

With respect to differences in the magnitude of the effects of WIN and ACPA, additional studies in the future will elucidate these mechanisms. However, ACPA has more selectivity for $\mathrm{CB}_{1}$ receptors and higher potency than WIN. Another possible explanation could be the fact that WIN and ACPA bind to a different site within the receptor. ACPA binds at residue 192 and the WIN binding site is possibly next to this site, in the third transmembrane domain of $\mathrm{CB}_{1}$ (Song and Bonner 1996). Moreover, it has been suggested that WIN binds to an uncharacterized non$\mathrm{CB}_{1}$ cannabinoid receptor (Breivogel et al. 2001) or vanilloid receptors, as has been suggested for blood vessel smooth muscle (Dannert et al. 2007). In addition, there is evidence of a $\mathrm{CB}_{1}$ splice variant $\left(\mathrm{CB}_{1 \mathrm{~A}}\right)$, which could be the one expressed in amphibian (Rinaldi-Carmona et al. 1996; Shire et al. 1995). Thus, it would be interesting to determine in the future the complete sequence of the cannabinoid receptor in this preparation to determine its nature as it may be a $\mathrm{CB}_{1}$ splice variant.

To our knowledge, this work is the first to show direct evidence of the existence of $\mathrm{CB}_{1}$ receptors and the diminishing of tension by synthetic cannabinoids on intact frog slow and fast muscle fibers. Our methodology conserves the entire cannabinoid signaling system of these intact skeletal muscle fibers.

Thus, the functional significance of the cannabinoid receptors in skeletal muscle would be the modulation of tension. This force modulation by cannabinoids would be done by acting on the extracellular binding site of the membrane and/or regulating the $\mathrm{Ca}^{2+}$ release from the sarcoplasmic reticulum (Hoock et al. 1996; Huerta et al. 1986; Krippeit-Drews and Schmidt 1992; Muñiz et al. 1992; Shabala et al. 2008). However, further research is necessary to elucidate these mechanisms.

Acknowledgments This work was supported, in part, by a grant from the Consejo Nacional de Ciencia y Tecnología (CONACYT-México, 42446-M and 83113, to M. H.) and by the grant Ramón Álvarez-Buylla de Aldana (FRABA, to M. H. and X. T.). E. S.-P., M. O.-M. and R. M.P. received CONACYT fellowships. Some portions of this work formed part of the PhD thesis of M. O.-M. at University of Colima (Colima, Mexico). The authors thank Professor Deborah Lewis from the Department of Pharmacology and Toxicology, Medical College of Georgia (Augusta, GA) for the donation of the human $\mathrm{CB}_{1}$ receptor cDNA. In addition, we thank Mr. Ezequiel Viera for technical assistance. The authors are also greatly indebted to the reviewers for their valuable comments, which improved the manuscript considerably. We dedicate this report to the memory of Dr. J. L. Marín.

Open Access This article is distributed under the terms of the Creative Commons Attribution Noncommercial License which permits any noncommercial use, distribution, and reproduction in any medium, provided the original author(s) and source are credited.

\section{References}

Alworth LC, Harvey SB (2007) IACUC issues associated with amphibian research. ILAR J 48:278-289

Baker D, Pryce B, Croxford JL, Brown P, Pertwee RG, Fuman JW, Layward L (2000) Cannabinoids control spasticity and tremor in a multiple sclerosis model. Nature 404:84-87

Baker D, Pryce B, Croxford JL, Brown P, Pertwee RG, Markriyannis A, Khanolkar L, Layard F, Rezza T, Bisogno T, DiMarzo V (2001) Endocannabinoids control spasticity in a multiple sclerosis model. FASEB J 15:300-302 
Beltramo M, Bernardini N, Bertorelli R, Campanella M, Nicolussi E, Fredduzzi S, Reggiani A (2006) $\mathrm{CB}_{2}$ receptor-mediated antihyperalgesia: possible direct involvement of neural mechanisms. Eur J Neurosci 23:1530-1538

Breivogel CS, Griffin G, Di Marzo V, Martin BR (2001) Evidence for a new $G$ protein-coupled cannabinoid receptor in mouse brain. Mol Pharmacol 60:155-163

Caputo C (1966) Caffeine- and potassium-induced contractures of frog striated muscle fibers in hypertonic solutions. J Gen Physiol 50:129-139

Cavuoto P, McAinch AJ, Hatzinikolas G, Cameron-Smith D, Wittert GA (2007a) Effects of cannabinoid receptors on skeletal muscle oxidative pathways. Mol Cell Endocrinol 267:63-69

Cavuoto P, McAinch AJ, Hatzinikolas G, Janovská A, Game P, Wittert GA (2007b) The expression of receptors for endocannabinoids in human and rodent skeletal muscle. Biochem Biophys Res Commun 364:105-110

Chaperon F, Thiebot MH (1999) Behavioral effects of cannabinoid agents in animals. Crit Rev Neurobiol 13:243-281

Chomczynski P, Sacchi NS (1987) Single-step method of RNA isolation by acid guanidinium thiocyanate-phenol-chloroform extraction. Anal Biochem 162:156-159

Dannert MT, Alsasua A, Herradon E, Martín MI, López-Miranda V (2007) Vasorelaxant effect of Win 55,212-2 in rat aorta: new mechanisms involved. Vascul Pharmacol 46:16-23

Dewey WI (1986) Cannabinoid pharmacology. Pharmacol Rev 38:151-178

DiMarzo V, Hill MP, Bisogno T, Crossman AR, Brotchie JM (2000) Enhanced levels of endogenous cannabinoids in the globus pallidus are associated with a reduction in movement in an animal model of Parkinson's disease. FASEB J 14:14321438

Filipeanu CM, de Zeeuw D, Nelemans SN (1997) Delta(9)-tetrahydrocannabinol activates $\left[\mathrm{Ca}^{2+}\right]_{i}$ increases partly sensitive to capacitative store refilling. Eur J Pharmacol 366:1-3

Glass M, Dragunow M, Faull RLM (1997) Cannabinoid receptors in the human brain: a detailed anatomical and quantitative autoradiographic study in the fetal, neonatal and adult human brain. Neuroscience 77:299-318

Gong JP, Onaivi ES, Ishiguro H, Liu QR, Tagliaferro PA, Brusco A, Uhl GR (2006) Cannabinoid $\mathrm{CB}_{2}$ receptors: immunohistochemical localization in rat brain. Brain Res 1071:10-23

Greenbaum D, Colangelo C, Williams K, Gerstein M (2003) Comparing protein abundance and mRNA expression levels on a genomic scale. Genome Biol 4:117

Hillard CJ, Manna S, Greenberg MJ, DiCamelli R, Ross RA, Stevenson LA, Murphy V, Pertwee RA, Campbell WB (1999) Synthesis and characterization of potent and selective agonists of the neuronal cannabinoid receptor $\left(\mathrm{CB}_{1}\right)$. J Pharmacol Exp Ther 289:1427-1433

Hollis DM, Coddington EJ, Moore FL (2006) Neuroanatomical distribution of cannabinoid receptor gene expression in the brain of the rough-skinned newt, Taricha granulosa. Brain Behav Evol 67:135-149

Hoock C, Steinmetz J, Schmidt H (1996) Caffeine-evoked contractures in single slow (tonic) muscle fibres of the frog (Rana temporaria and $R$. esculenta). Pfluegers Arch 432:207214

Howlett AC, Barth F, Bonner TI, Cabral G, Casellas P, Devane WA, Felder CC, Herkenham M, Mackie K, Martin BR, Mechoulam R, Pertwee RG (2002) International union of pharmacology. XXVII. Classification of Cannabinoid receptors. Pharmacol Rev 54:161-202

Huerta M, Muñiz J, Stefani E (1986) Effects of external calcium on potassium contractures in tonic muscle fibres of the forg (Rana pipiens). J Physiol 376:219-230
Institute for Laboratory Animal Research Guide for the care and use of laboratory animals (1996) Commission on life science. National Research Council, pp 1-150

Klein MG, Simon BJ, Schneider MF (1990) Effects of caffeine on calcium release from the sarcoplasmic reticulum in frog skeletal muscle fibres. J Physiol 425:599-626

Krippeit-Drews P, Schmidt H (1992) Effects of $\mathrm{Ca}^{2+}$ and other divalent cations on $\mathrm{K}^{+}$-evoked force production of slow muscle fibers from Rana esculenta and Rana pipiens. J Membr Biol 129:211-220

Kuffler SW, Vaughan-Williams EM (1953) Properties of the slow skeletal muscle fibres of the frog. J Physiol 121:318-340

Mackie K (2006) Cannabinoid receptors as therapeutic targets. Annu Rev Pharmacol Toxicol 46:101-122

Matsuda LA, Lolait SJ, Brownstein MJ, Young AC, Bonner TI (1990) Structure of a cannabinoid receptor and functional expression of the cloned cDNA. Nature 346:561-564

McPatland JM, Matias I, Dimarzo V, Glass M (2006) Evolutionary origins of endocannabinoids system. Gene 370:64-74

Meccariello R, Chianese R, Cacciola G, Cobellis G, Pierantoni R, Fasano S (2006) Type-1 cannabinoid receptor expression in the frog, Rana esculenta, tissues: a possible involvement in the regulation of testicular activity. Mol Reprod Dev 73:551-558

Muñiz J, Huerta M, Dueñas J, Trujillo X, Elizalde A (1992) Caffeine and theophylline contractures in tonic skeletal muscle fibers of the frog. Jpn J Physiol 42:711-720

Munro S, Thomas KL, Abu-Shaar M (1993) Molecular characterization of a peripheral receptor for cannabinoids. Nature 365:61-65

Ortiz-Mesina M, Trujillo X, Sánchez-Pastor E, Montoya-Pérez R, Castro E, Vásquez C, Onetti C, Huerta M (2007) Effect of cannabinoid agonist ACPA on caffeine contractures in fast and slow muscle fibers of Rana pipiens. Society for Neuroscience, 37th Annual Meeting, Nov 3-7, 2007, San Diego, CA, p A878.11

Pagotto V, Marsicano G, Cota D, Lutz B, Pasquali R (2006) The emerging role of the endocannabinoids regulation and energy balance. Endocr Rev 27:73-100

Parolaro D (1999) Presence and functional regulation of cannabinoid receptors in immune cells. Life Sci 65:637-644

Pertwee R, Coutts A, Griffin G, Fernando S, Mccallion D, Stevenson $\mathrm{L}$ (1996) Presence of cannabinoid $\mathrm{CB}_{1}$ receptors on prejunctional neurones of certain isolated tissue preparations: a brief review. Med Sci 2:840-848

Piomelli D (2003) The molecular logic of endocannabinoids signaling. Nat Rev Neurosci 4:873-884

Reisine T, Law SR (1992) Pertussis toxin in analysis of receptor mechanisms in neurotoxins. In: Methods in neuroscience. Academic Press, San Diego, pp 358-367

Rinaldi-Carmona M, Calandra B, Shire D, Bouaboula M, Oustric D, Barth F, Casellas P, Ferrara P, Le Fur G (1996) Characterization of two cloned human $\mathrm{CB}_{1}$ cannabinoid receptor isoforms. J Pharmacol Exp Ther 278:871-878

Rodriguez de Fonseca F, Del Arco I, Bermudez-Silva FJ, Bilbao A, Cippitelli A, Navarro M (2005) The endocannabinoids system: physiology and pharmacology. Alcohol Alcoholism 40:2-14

Ross R (2003) Anandamide and vanilloid TRPV1 receptors. Br J Pharmacol 140:790-801

Salio C, Cottone E, Conrath M, Franzoni MF (2002) CB $_{1}$ cannabinoid receptors in amphibian spinal cord: relationships with some nociception markers. J Chem Neuroanat 24:153-162

Salzet M, Breton C, Bisogno T, DiMarzo V (2000) Comparative biology of endocannabinoids system. Possible role in the immune response. Eur J Biochem 267:4917-4927

Sánchez-Pastor E, Trujillo X, Huerta M, Castro E, Vásquez C, Andrade F (2004) Presence of mRNA for cannabinoid receptor $\left(\mathrm{CB}_{1}\right)$ in frog and chicken skeletal muscle fibers. In: Biophysical 
Society 48th Annual Meeting, Feb 14-18, 2004, Baltimore, MD. Biophysical Society, Bethesda, MD, p A2179. http://www.bio physics. org/

Sánchez-Pastor EA, Huerta M, Trujillo X, Andrade F (2007) Effects of cannabinoids on synaptic transmission in the frog neuromuscular junction. J Pharmacol Exp Ther 321:439-445

Sañudo-Pena MC, Romero J, Seale GE, Fernandez-Ruiz JJ, Walker JM (2000) Activational role of cannabinoids on movement. Eur J Pharmacol 391:269-274

Schlicker E, Kathmann M (2001) Modulation of transmitter release via presynaptic cannabinoid receptors. Trends Pharmacol Sci 22:565-572

Schweitzer P (2000) Cannabinoids decrease the $\mathrm{K}^{+}$M-current in hippocampal $\mathrm{CA}_{1}$ neurons. J Neurosci 20:51-58

Shabala L, Sánchez-Pastor E, Trujillo X, Shabala S, Muñiz J, Huerta $M$ (2008) Effects of verapamil and gadolinium on caffeineinduced contractures and calcium fluxes in frog slow skeletal muscle fibers. J Membr Biol 221:7-13

Shire D, Carillon C, Kaghad M, Calandra B, Rinaldi-Carmona M, Le Fur G, Caput D, Ferrara P (1995) An amino-terminal variant of the central cannabinoid receptor resulting from alternative splicing. J Biol Chem 270:3726-3731
Soderstrom K, Leid M, Moore FL, Murriat F (2000) Behavioral, pharmacological, and molecular characterization of an amphibian cannabinoid receptor. J Neurochem 75:413-423

Song ZH, Bonner TI (1996) A lysine of the cannabinoid receptor is critical for receptor recognition by general agonists but not WIN55212-2. Mol Pharmacol 49:891-898

Sugiura P, Ko CP (1997) Novel modulatory effect of L-type calcium channels at newly formed neuromuscular junctions. J Neurosci 17:1101-1111

Velasco R, Trujillo X, Vasquez C, Huerta M, Trujillo-Hernandez B (2003) Effect of dimethyl sulfoxide on excitation-contraction coupling in chicken slow skeletal muscle. J Pharmacol Sci 93:149-154

Wiley JL, Martin BR (2003) Cannabinoid pharmacological properties common to other centrally acting drugs. Eur $\mathrm{J}$ Pharmacol 471:185-193

Xin H, Tanaka H, Yamaguchi M, Takemori S, Nakamura A, Kohama $\mathrm{K}$ (2005) Vanilloid receptors expressed in the sarcoplasmic reticulum of rat skeletal muscle. Biochem Biophys Res Commun 332:756-762 